\title{
“Secularization” or Plurality of Meaning Structures? A. Schutz’s Concept of a Finite Province of Meaning and the Question of Religious Rationality
}

\author{
Marek Chojnacki \\ Ul. Szkolna, Izabelin, Poland \\ Email: mchojnacki@go2.pl \\ Received March 2 ${ }^{\text {nd }}$, 2012; revised April 4 ${ }^{\text {th }}$, 2012; accepted April 15 ${ }^{\text {th }}, 2012$
}

\begin{abstract}
Referring to basic Weberian notions of rationalization and secularization, I try to find a more accurate sense of the term "secularization", intending to describe adequately the position of religion in modernity. The result of this query is - or at least should be-a new, original conceptualization of religion as one of finite provinces of meaning within one paramount reality of the life-world, as defined by Alfred Schutz. I proceed by exposing a well known, major oversimplification of the Weberian concept of secularization, very well outlined in Peter Berger's The sacred canopy, in order to point to the genuine, much more differentiated position of Max Weber in this matter (especially from the period of Foundations of social economic and Economy and society), and, consequently, to return to the roots of Berger's thought: phenomenological sociology of Alfred Schutz, an attempt to assure the philosophical foundations of Weber's sociological theory. At a closer glimpse, transformation of religion in the modern process of rationalization does not consist-according to Weber-in eliminating religion and thus depriving society of the religious source of meaning, but in parallel emancipation of many different domains of rationality, including religion itself. Using Schutz's analysis of the social world as a complex structure of many different final provinces of meaning, I describe religion as such a province and show what does the process of rationalization of this province consist and what it should consist in: a complex, ongoing exchange of cognitive relevances and contents, combined with growing autonomy of many different sub-worlds. Schutz's theory of symbol, rooted in Edmund Husserl's description of constitution of complex objects in mono- and polythetic acts of consciousness, moves the analysis to the epistemological level, pointing to a chance of intensifying our cognitive relation to reality through increasing interpenetration of various sub-universes of meaning.
\end{abstract}

Keywords: Religion; Rationality; Modernity; Secularization; Phenomenological Sociology; Finite Provinces of Meaning; Life-World; Emancipation; Epistemology

\section{An Ambitious Question Profiting from a Major Ambiguity}

Irrespective of what we think of the claim of religions to their truths and of their place in the modern society, they continue play an important role in shaping social institutions, patterns of behavior and ways of thinking. But, contrary to the situation a century ago, we seem to know less and less about the social role and position of religion, in spite of common theorems and descriptions pertaining to this domain of social world, theorems and descriptions that we use to take for granted. A paradigmatic example of such a theorem, only seemingly evident, provides the notion of secularization, introduced to reflection on society mostly by Max Weber's social theory and reinterpreted subsequently in the second half of the twentieth century in the analyses of such authors as Peter L. Berger (The sacred canopy, 1967), Thomas Luckmann (The invisible religion, 1963), David Martin (The religious and the secular, 1969), Bryan Wilson (Religion in sociological perspective, 1982), and most recently Jose Casanova (Public religions in the modern world, 1994). It is interesting that all these analyses prevails the oversimplified understanding of secularization as a process of elimination of religion as the main (or only) source of meaning in society and of its replacement by other social domains, such as science, state and the like. With such a notion of secularization, it seems to be really difficult to know what we are talking about. Jose Casanova, considered to be one of the most eminent and pertinent secularization theorist, describes the recent discussion on this subject as "the often fruitless secularization debate” (Casanova, 2006: p. 8). Even he, however, although (mostly under influence of Talcott Parsons' functional theory) recognizing "differentiation of the secular spheres" as one of the aspects of secularization, defines this phenomenon in the first place as "decline of religious beliefs and practices in modern societies” (Casanova, 2006: p. 7).

The purpose of the present analysis is, however, not to study the history of the notion of secularization or to take stance towards every-be it even the most important—view formulated in this regard. Taking reinterpretation of the Weberian notion of secularization as its point of departure, it wants first of all to profit from the ambiguous theoretical situation outlined above to reformulate the question about religion and its claims and to ask about its cognitive and social potential, other than being the unique source of meaning in society. An expected result of such an approach may be not only a new understanding of religion, 
but also of the whole process of socialization, of social rationality and of its cognitive potentialities. Such an ambitious goalfascinating beyond any doubt-forecloses obtaining precise and accomplished results in such a short and introductory query, which wants only to initiate and outline a new approach. Hence the unaccomplished character of its conclusions, intending rather to inspire further research than to offer well defined answers.

\section{Secularization as Elimination of Religion? Questioning Weber about Berger's Sacred Canopy}

The postweberian tradition of the sociology of religion yields unexplored possibilities of interpreting the concept of secularization, to the extent that it is possible to question if its use for a so long time in the reflection on religion and society wasn't a kind of misunderstanding. An eminent example of such a reinterpretation offers us Catherine Colliot-Thélène in her essay on disenchantment and rationalization in Weber (Colliot-Thelene, 1995). Referring to the late Weberian sociology of religion, developed after his famous The protestant ethic and the spirit of capitalism, she makes the point that it is unjustified to place his analyses in the frame of interpretation of secularization theories. The frame of interpretation of secularization theories, claiming that the essential difference between the modern and the premodern world consists in emancipation from the decisive influence of religion on the constitution of society, fail to do justice to Weberian analyses because they assume that the essential role of religion in society is to be the sole source of meaning (Colliot-Thelene, 1995: p. 73). Colliot-Thélène quotes the example of The sacred canopy of Peter Berger (Berger, 1967), inspired by Weber, where the term "secularization” denotes the situation of religion thrown into the market of commercial competition, deprived of its original power to bestow the common meaning upon society and thus leaving it in a primordial state of chaos and anomy (Colliot-Thelene, 1995: p. 74).

Berger's formulation of the loss of meaning resulting from the secular turnover is indeed powerful:

"The world as defined by the religious institution ( $\cdots)$ was the world ( $\cdots)$. To step outside the world as religiously defined was to step into a chaotic darkness, into anomy, possibly into madness.” (Berger, 1967: p. 135).

Paraphrasing Durkheim, we could say that in the face of such massive meaninglessness, the only way out for the common man is suicide. Paradoxically, it may be said — even without a detailed analysis - that contemporary theologies of secularization, quoted by Berger as positions opposite to his own (Berger, 1967: 106f, 155f), such as D. Bonhoeffer's vision of "religionless Christianity” or H. Cox's Secular city, carried along the same implicit effort to present religion as the exclusive source of meaning in premodern society, rejected in the process of emancipation that was initiated by Enlightenment. ${ }^{1}$ The question raised by Colliot-Thélène is whether such a vision corresponds to interpretations of religion contained in M. Weber's sociohistorical analyses, inspiring, as it seems, Peter Berger.

${ }^{1}$ See e.g. Bonhoeffer's concept of man's and world's autonomy in his letter to Eberhard Bethge form 16 July 1944, in: Bonhoeffer, 1971, pp. 359-361; similarly Cox's opposition between tribal religious society and secular city, see Cox, 1990, pp. 9-11, 230.

\section{Plurality of Meaning Structures. Weber's Broader Understanding of Secularization}

If The protestant ethic dealt mainly with the relation between changes within Christianity as a relatively independent domain and the beginnings of capitalism, in Weber's later studies on religion we find a shift of interest towards a more general relation between the basic web of social life, which we would call today the "life-world", and the process of general rationalization of the life-world, in the double sense of means-ends rationality and of development of moral goals. This shift, characteristic of all of Weber's analyses since the project of Foundations of social economics, is testified by his wife and biographer, Marianne Weber, as focusing on the global process of rationalization, the same in many different domains of social life, such as religion, economy, law, ethics, aesthetics and science, which in this particular regard become its partial manifestations (Teilerscheinungen) (Weber, 1975; Colliot-Thelene, 1995: p. 64).

Thus, in The sociology of religion, Weber's late synthesis on the subject in question (Weber, 1963), relations between religious patterns and the emerging capitalist society aren't described as eliminating one Durkheimian quasitranscendental principle of unity and meaning in favor of another (or lack of it), but rather as a complex process of changes in those patterns, increasingly accounting for needs and pursuit of meaning in the changing society. So for example a Weberian priest differs from a magician by degree of generalizing religious patterns, moving from a direct satisfaction of everyday religious needs to images and structures stabilizing and institutionalizing society. But his role, in comparison to a prophet, representing the ethical type of religious rationalization, is still essentially oriented toward everyday needs: priests, by their institutional constitution, are obliged to serve laymen. What results from the compromise between institutionalized instruction, satisfaction of everyday religious needs and high ethical standards of prophets is what Weber calls "pastoral care" (Weber, 1963: pp. 1-79). Independent intellectual movements, processing metaphysical, ethical and soteriological questions, are conceived here rather as counterbalance for monopolizing these questions by priesthood, characteristic of all ages, than as a radical emancipation from religion, seemingly characteristic of modernity (Weber, 1963: pp. 118-137). Even the confrontation of types of "salvation religion" with requirements of modern economical structures turns out to be a positive evaluation of religion in the frame of modernity, since one of these types, "inner-worldly asceticism", presenting the world "to the religious virtuoso as his responsibility", is the factor that puts economical life in motion (Weber, 1963: pp. 138-222). Weber's rather pessimistic conclusion that "only Protestantism completely eliminated magic and the supernatural quest for salvation, of which the highest form was intellectualist, contemplative illumination”, and that "it alone created the religious motivations for seeking salvation primarily through immersion in one's worldly vocation (Beruf)" (Weber, 1963: pp. 269-270) results from the limitations of his historical and cultural horizon, restricted, in spite of the enlargening the research field, to that of The protestant ethic, and has nothing to do with suggesting the decline of religion as such (Colliot-Thelene, 1995: p. 67). Briefly, as Colliot-Thélène puts it, the main interest of Weber's analyses isn't the opposition between the inner-worldly and the hereafter (diesseits/jenseits) orientation, suggesting the totalizing charac- 
ter of religion and its elimination in the modern world, but the distinction between (religious and other) orientations, rooted in everyday life and those uprooted from it (Alltäglichkeit/ Außertäglichkeit). The life-world, the cardinal locus of economy, is his main point of reference, in respect to which all other domains are evaluated (Colliot-Thelene, 1995: p. 75).

\section{Rationalization Rooting in the Life-World. New Chances for Religion}

If the life-world, more than religion or anything else, is the primary source of meaning, then what-if not eliminating religion as the only source of meaning-constitutes from the Weberian perspective the specific position of religion in the frame of modernity? Berger's complaints about the disastrous character of this position may be helpful in answering this question:

"As a result of secularization religious groups are also compelled to compete with various non-religious rivals in the business of defining the world, some of them highly organized ( $\cdots)$, others much more diffused institutionally. ( $\cdots$ ) The worldbuilding potency of religion is thus restricted to the construction of sub-worlds, of fragmented universes of meaning, the plausibility structure of which may in some cases be no larger than the nuclear family.” (Berger, 1967: pp. 134, 137).

Berger's description of many different religious and non-religious instances, of many different sub-worlds competing in defining meaning, seems to be quite accurate and may be taken for an adequate image of religion's situation in modernity. But the purely negative estimation of this situation, suggested by Berger, doesn't seem to be defensible when confronted with his own analysis on religion and alienation, effectuated in the former chapter of his book (Berger, 1967: pp. 81-101). Dangers of religion as false consciousness, turning religious mystery into a terrifying alien force and overlegitimizing political power, appear in this analysis to be coalesced with what Berger, after Sartre, calls attitude of bad faith, or, in Meadian terms, a total incorporation of the "I", the subject of social action, by the "me", i.e., the social role the subject is playing. Such an attitude entails a severance, in consciousness, of the dialectical relationship between man (as a believing subject) and his product (religion):

"The duplication of consciousness brought about by socialization and the concomitant internalization of the socio-cultural dialectic is thus denied. A false unity of consciousness is posited instead, with the individual identifying himself totally with the internalized roles and the socially assigned identity constituted by them. For example, any relevant expressions of self not channeled in the role of faithful husband are denied. Put differentially, the internal conversation between husband and (potential) adulterer is interrupted. The individual sees himself as nothing but a husband in those areas of his life to which this role pertains. He has become a husband tout court, the husband of the institutional dramatis personae.” (Berger, 1967: p. 94).

Berger tries here a very original reinterpretation of the classical concept of false consciousness, based on the distinction between subjects as original sources of social roles and structures and these structures and roles cut off from their subjective source. It seems to be very important that when the subjective source is taken into account, a plurality of many different roles and meaning structures-even contradictory, as in the case of the roles of husband and adulterer-emerge from the complex web of human relations. A basic question implied by this analysis is whether it is possible to assume such a plurality without falling inescapably into the primordial chaos of meaninglessness, if one presupposes that there is only one source of meaning in the social world. The assumption of religious objectivation as the only means of constituting sense in society and the assumption of subjective distance toward objectivations seem to exclude each other. The social actor is supposed to perform constant leaps from one objectivization to another through the empty space of meaninglessness, which, according to previous assumptions, should destroy his world. Therefore, Berger's efforts to escape the danger of false consciousness remind somehow of baron Munchhausen, trying to get out from the bog by pulling his own hair.

It would be more consistent to assume, on the grounds of the Weberian positions, that the process of rationalization has led in modernity to the highly reflexive acceptance of many different domains of meaning-among which religion has its own position, but is scarcely a solitary one-thus escaping the danger of "false unity of consciousness". This status quo of plurality isn't as a matter of fact a revolution, but rather a development, since other domains contributing to the human quest for meaning always existed as constitutive of human consciousness. Their autonomy may be seen positively as a part of a tendency to make explicit this quest, the proper and original locus of which is the life-world.

Such an interpretation of Berger's diagnosis has, apart from its consistency, another advantage in comparison to Berger's pessimism: it isn't in principle at odds with the way religions used to define themselves. To the self-definition of religion usually belongs a claim that certain contents of beliefs are true, independently of the role and function religion plays in society, whereas the Durkheimian model of interpretation, assumed by Berger, grasps it only as a purely formal means of enforcing social unity, external to our perception of reality and appearing as a purely human and social product. It is much easier to reconcile religious claims to truth with a vision of their social structure that considers religion as rooted in our common perception of the world, where something like revelation, illumination or any other form of radical givenness of the supreme being and meaning seems quite possible.

\section{Alfred Schutz: The Notion of a Finite Province of Meaning}

When Peter Berger speaks of "sub-worlds", or "fragmented universes of meaning", he seems to paraphrase consciously the James-Schutz conception of the plurality of meaning structures. For William James, the accent on the "various orders of reality", the "many worlds" or "sub-universes" of human experiences expressed a belief that, as Alfred Schutz puts it, "reality means simply relation to our emotional and active life; whatever excites and stimulates our interest is real” (James, 1890: pp. 283324; Wagner, 1970: p. 252). Such a standpoint highlights the subjective grounding of our perception of reality, but at the same time relativizes it and pushes it toward a mere subjectivism. Schutz, the founder of sociophenomenology, takes over from James the concept of various reality orders, but not in the sense of separate independent "sub-universes". As he puts it,

"We prefer to speak of finite provinces of meaning upon which we bestow the accent of reality, instead of subuniverses as does William James. By this change of terminology we emphasize that it is the meaning of our experiences, and not the 
ontological structure of the objects, which constitutes reality.” (Schutz, 1970: p. 1, p. 252; Schutz, 1962: p. 230).

Let us remark, to begin with, that Schutz means here provinces of meaning, i.e., not the separate "worlds" projected by many individuals on many occasions, but domains of something that can be universally grasped and what gives the unity and content necessary to fill a proper act of cognition, as well as to sustain social life. Berger's expression "fragmented universes of meaning" tries to short-circuit this difference: even if there is any "meaning" in quasi-universes, left after the bigbang of modernity, it is fragile, unable to endow them with unity and stability. In other words, the above-mentioned expression reflects Berger's fundamental disbelief in the possibility of meaning in the world deprived of one religious order of universal meaning, encompassing all domains of life, whereas Schutz proposes a theory of many finite provinces of meaning (including, as we will see, religion), contributing to a stable web of social world. What may be astonishing is that Berger feels obliged to use in this context the term meaning.

The key to Schutz's concept of the finite province of meaning is his basic project of sociophenomenology, conceived as exploration of meaningful structures of the life-world, as phenomenology of the natural attitude. For the world of daily life is the intersubjective space where meaning, i.e., the universum of goals and means, is constituted in the course of interactions, where "we both, I and the Other, experience the ongoing process of communication in a vivid present” (Schutz, 1962: p. 219). In this space "the physical objects of nature are transformed into sociocultural objects” (Schutz, 1970: p. 253), obtaining their first and basic interpretation in terms of human action. That's why the world of everyday life is the paramount reality in relation to all other sociocultural interpretations, developing and concretizing the human quest for meaning: it endows them not only with the raw material, but gives them their core which must be further interpreted according to their specific character. These specific interpretations-finite provinces of meaningthus obtain what Schutz calls the accent of reality: their linkage with the universe of meaning directly grasped in the full attention to life, through the suspension of doubt in whatever appears to be real and meaningful. The more specific are finite provinces of meaning in determining their own field of interest, in making meaning more clear and distinct from that grasped within others, the more distant they are from attention to life, moving on the scale of phenomenological reduction away from the suspension of doubt towards the suspension of belief. "A typology of the different finite provinces of meaning could start from an analysis of those factors of the world of everyday life from which the accent of reality has been withdrawn"; "what then remains outside the brackets could be defined as the constituent elements of the cognitive style of experiences belonging to the province of meaning thus delimited" (Schutz, 1962: p. 233).

The tension between the suspension of doubt and the suspension of belief, between the epoché of the natural attitude and different epochés of finite provinces of meaning is thus the way Schutz defines different domains contributing to the constitution of meaning. Specific epochés having their absolute model beyond the natural attitude, in the phenomenological epoché sensu stricto, where the belief is suspended about the world as such, leaving only the pure content of intentional acts of consciousness. Schutz tries to describe in detail such provinces of meaning as phantasms, dreams and science, social science in particular (Schutz, 1970: pp. 256-292; Schutz, 1962: pp. 234259). Although he doesn't attempt to describe religion in the same way, he mentions it along with art as an eminent example of specificity of finite provinces of meaning. Moreover, he mentions "the leap into the religious sphere" together with the scientific "disinterested contemplative attitude", thus confirming the principal position of the religious domain of meaning in the world of human culture (Schutz, 1970: p. 255; Schutz, 1962: p. 344).

\section{Religion as a Finite Province of Meaning}

For our purposes, we can try to develop, on the basis of Schutz's basic definitions, a brief description of religion as a particular finite province of meaning, characterized by the suspension of doubt in the world as it is grasped from the religious point of view. The world, under influence of a specific religious experience, is apprehended in relation to some supreme being or principle, as creation, Maya, emanation of Godhead, scene of action of gods or God, scene of revelation or in any other way. Such a cognitive attitude entails development of particular belief systems, or religious traditions, consisting of socially transmitted symbols and attitudes pertaining to the world of everyday life and attempting to influence it. This particular mutual relation between the paramount reality and religious reality, constituting a kind of feedback, seems to be the main characteristic of religion from the functional point of view and brings it close to such provinces of meaning as science or art. This feedback relation, depending on the cultural context and degree of rationalization of social life, may be simple and directbeing then perceived as "the only source of meaning", although actually it is never the case-or indirect and counterbalanced by other regions of meaning emancipated from its dominance. But it remains always the essential constituent moment of religion. Influence of science or ideology on the everyday life can be a secondary effect or an attempt of external control: religion is always - at least in the consciousness of believers-a way of living.

According to Schutzian assumptions, there is always another side of the peculiar suspension of doubt, characteristic of a given finite province of meaning, namely the particular suspension of belief. In the case of religion, it seems to be the refusal to accord relevance and status of reality to any element of the life-world that appears to be at odds with the belief system produced by the religious cognitive attitude within a given religious tradition. Paraphrasing the strict phenomenological language of Husserl, we may say that the religious attitude "switches off" the explanatory power of those meaning structures and those objects aperceived and apresented in the natural attitude that collide with the present status quo of the belief system.

\section{Alfred Schutz: A Net of Provinces of Meaning. Passages between Them and Their Unity}

Before we try to specify more closely the suspension of belief, characteristic of the religious reality, and its consequences, we should ask how Schutz defines relations between different finite provinces of meaning. First of all, all members of the social world live in one paramount reality of everyday life, and that paramount reality enables switching their cognitive attitudes from one province of meaning to another. Schutz states that such leaps are accompanied by shocks, resulting from the 
radical change of world perception. Their abrupt nature manifests itself in many different manners:

"There are as many innumerable kinds of different shock experiences as there are different finite provinces of meaning upon which I may bestow the accent of reality. Some instances are: the shock of falling asleep as the leap into the world of dreams; the inner transformation we endure if the curtain in the theater rises as the transition into the world of stageplay; the radical change in our attitude if, before a painting, we permit our visual field to be limited by what is within the frame as the passage into the pictorial world; ( $\cdots)$. But also the religious experiences in all their varieties-for instance, Kierkegaard's experience of the "instant" as the leap into the religious sphereare examples of such a shock, as well as the decision of the scientist to replace all passionate participation in the affairs of “this world” by a disinterested contemplative attitude." (Schutz, 1970: pp. 254-255; Schutz, 1962: p. 231).

In our attempt to describe the religious suspension of doubt we have pointed out to the fact that it is possible to typify finite provinces of meaning according to the degree of influence on the world of everyday life, to their feedback relation with it. Let's see now what happens to the category of leap if we apply this typification. If the finite province of meaning shows ex definitione little interest in "what really happens and should happen" in the everyday world, as for instance (under certain conditions) in the case of dream, fantasy, or even art, then a leap from such a province to another is abrupt, but neutral. If, on the contrary, provinces are engaged in redefining the life-world, it may happen that passing from one to another we realize that different provinces try to define it in a radically different manner. It comes then to an open conflict between the provinces of meaning.

If we take into account this potential conflictory aspect of the religious province of meaning, the religious natural suspension of belief appears to be a guard of its borders, a kind of a power shield protecting religious rationality from alien intruders. But, on the other hand, as Schutz puts it,

"we are always living and acting simultaneously in several of these provinces, and to select one can merely mean that we are making it so to speak our 'home base', 'our system of reference', ( $\cdots)$ in relation to which all others receive merely the accent of derived reality-namely, they become horizontal, ancillary, subordinate in relation to what is the prevailing theme.” (Schutz, 1970: p. 11).

There is no absolute starting point from which we start interpreting reality; Schutz seems to stand here firmly on the nonfoundationalist positions. The theme-field relation, i.e., the basis of choice of a given province of meaning changes constantly, and asking about the beginnings of choosing one rather than another, we are inescapably faced with the fallacy of petitio principii (Schutz, 1970: p. 11). Moreover, we live simultaneously in many different provinces of meaning, what brings in question the very notion of leaps from one to another, at least if we understand leaps as a mere sequence of different manners of cognition. This leads to astonishing conclusions:

"The corollary to the fact that we live simultaneously in various provinces of reality or meaning is the fact that we put into play various levels of personality-and this indicates a hidden reference to the schizophrenic-ego hypothesis." (Schutz, 1970: p. 11).

In order to understand what Schutz has in mind and to escape the danger of treating his deliberations as an invitation to madness ${ }^{2}$, we have to change the kind of metaphors from visual to auditory ones, what was one of Schutz's most important modifications of Husserl's phenomenology. In the domain of music:

"the listener's mind may pursue one [motive] or the other, take one as the main theme and the other as the subordinate one, or vice versa: one determines the other, and nevertheless it remains predominant in the intricate web of the whole structure. It is this 'counterpointal structure' of our personality and therewith of our stream of consciousness which is the corollary of what has been called in the other connections the schizophrenic hypothesis of the ego-namely the fact that in order to make something thematic and another thing horizontal we have to assume an artificial split of the unity of our personality." (Schutz, 1970: p. 12).

Now, how it is possible to assume the existence of the natural suspension of belief in its "hard" version of a sharp boarder, proper, e.g., to the religious province of meaning, together with the counterpointal structure of consciousness, demanding a continuous flux of our relevance systems? It seems necessary to introduce a new category of a critical suspension of belief, bracketing in a provisional way the external structure of a given province of meaning and thus making the necessary exchange of relevances possible. Similarly as R. M. Zaner speaks about Schutzian phenomenology of the life-world as a kind of epoché of second degree, suspending the suspension of doubt proper to each domain of meaning thematic (Zaner, 1970: p. 12), so and we could imagine a suspension of the suspension of belief, making thematic the exchange of relevances and the process of inner modification of a given province of meaning. Before, however, we turn to the analysis of what such a critical suspension may be, some explanatory remarks are necessary about how the question of the position of religion among other provinces of meaning, especially in the context of modernity, is related to the Schutzian conception of the counterpointal structure of the social construction of reality.

\section{Religion within the Net of Provinces of Meaning. Schutz's Theory of Symbol}

If we take into account the feedback relation of religion, outlined above, then we must assume that this province of meaning was somehow always in conflict with other provinces havingat least partially - the same character. The rationalization process in the Weberian sense, consisting in clarification and complexification of the means-ends structure, led to the increasing autonomy of provinces of meaning other than religion and consequently to the increase of their feedback function in relation to the life-world. This, in turn, led to inevitable conflicts between religion and such social domains possessing their own major provinces of meaning as science or politics, so visibly marking the history of the European civilization since Renaissance. With reference to religion this process may be called secularization, but hardly in the sense of eliminating-fortunately or unfortunately-religion from the set of factors constituting meaning in society. Religion-or, in extreme cases, its substitutes-was and still is a valid autonomous province of meaning, even in the most "secularized" parts of the world.

But the process in question goes on, and even particular "in-

${ }^{2}$ Schutz, of course, explicitly denies identity of the "schizophrenic ego" with the ego of patological schizophreny, cf. Schutz, 1970: p. 13. 
ner horizons” of experience ${ }^{3}$, inherent to particular social roles and contexts, gain their independence, constituting their own versions of relevance systems, of priorities, means and goals, and becoming finite provinces of meaning on their own. We normally do not notice how different are relevance systems attached to our different social roles - of parents, of subjects of the world of science, economy, politics, of church membersbecause, living simultaneously in all of them, we manage to establish a provisional harmony between these relevance systems, however vulnerable such a harmony might be. But the process of rationalization brings them to the fore as independent provinces of meaning, exposing inescapable conflicts between them as problems given and elaborated in the collective consciousness. The situation of a pregnant middle class college student on the way to her career, who is a practicing Catholic and is tempted to commit abortion, of a Christian favelas habitant, torn between the alternatives to "hate her/his neighbor" or to fall prey to an oppressive economic system, or of a religious terrorist, having the choice to kill innocent people or to surrender her/his nation to the unjust political force may serve us as some extreme ad hoc examples. It should be added that those situations, and many other similar situations, aren't new or specific to modernity: they actually always occurred. What makes the difference-easily labeled as "secularization"-is that now, instead of conceding privy compromises, usually eliminating claims of one or another relevance system, we have to consciously deal with tensions between systems of relevance, and that they challenge us to modify them and to integrate them in some higher, more reasonable meaning structure.

How to deal with these tensions? It is more reasonable to ask how they are in fact dealt with than to invent theoretical projects intending to "solve the problem". In quest for a suitable description let's turn once again to Schutz's sociophenomenology, this time specifically to his theory of symbol, which can give us a clearer idea of the critical suspension of belief. Schutz tries to develop a theory of creative leaps between meaning provinces, corresponding to the somehow dramatic situation of living simultaneously in many of them. This theory is based on reinterpretation of Husserl's description of the complex structure of cognitive intentionality in terms of description of the structure of choice. A complex act of cognition (and choice), in which the object is fully appresented-a polythetic act for Husserl-is composed of many single constituent monothetic acts, having a single shaft of attention or ray (Strahl) of awareness directed toward an object. Important here is the difference between what Husserl calls continuous synthesis-an accomplishment of a polythetic act binding together single acts with contents fitting together unproblematically, like in the case of particular appearances of a thing in space-and discontinuous synthesis, binding acts the relation of which to one another is more problematic. In the latter case the unity thus formed is called a unity of a higher order. But the synthetic act, being a many-rayed reference to an object, is not satisfied in being a plural consciousness. It tends to transform itself into a single consciousness, becoming anew a monothetic act, with a “one-rayed object” (Schutz, 1970: pp. 150-151).

The very notion of discontinuity inscribed in the dialectical logic of choice reminds us of the radical discontinuity of intersubjectively conditioned consciousness performing constant leaps, or even more, simultaneously oscillating between many

${ }^{3}$ About Husserl's notion of "inner horizon" see Schutz, 1975, p. 9. $93 f$. different provinces of meaning. The task of such a consciousness, synthesizing apparently heterogeneous elements, is all but easy and simple. It seems to be torn apart between two essential directions: accounting for the source of our knowledge and choice, for the very givenness of meaning, associated with the polythetic structure of our choices, and, on the other hand, the clarity and distinctness of choice and knowledge, acquired by a monothetic act (Schutz, 1970: pp. 80-82). We may add that the increase of realizing this dialectics, combining two kinds of dynamics of consciousness - the tendency to increase the clarity and distinctness on the one hand and the accountability of sources on the other-is the essence of what Weber called the process of rationalization and what we could somehow paradoxically call emancipation of the life-world.

\section{Filling Gaps after Passage. Intensifying the Exchange of Meaning}

We come then to the central question, crucial in the Schutzian theory of symbol, namely, how do we accomplish monothetic acts concerning meaning in the situation of discontinuity of appresentation, caused by the fact that "we live simultaneously on different levels of reality (provinces of meaning)" (Schutz, 1970: p. 104). When I leap from one to another, some topics important in the previous province disappear from my eyes, not even as a set of impressions and images, but as a meaningful structure, because topics of our previous experiences now lack particular systems of relevance, necessary to fill them with meaning. Schutz gives here a particularly clear example of awakening: I remember dreaming something, but the real content of the dream is absent, since I am no longer able to believe that my vital interest is to "find my way out of the magic spell which barred me from running after the person in whose hands (I was certain, while dreaming) was kept the secret of my existence” (Schutz, 1970: pp. 105-106). What can I do to reconstitute the lost meaning of my dream, somehow necessary for the unity of a higher order embracing all provinces of meaning, toward which I strive? The meaning of the dream is no longer there; but when I think of it, I discover an empty space left in my consciousness after withdrawing the system of relevance of the dream world; now, I must "work hard" "to modify my present relevance system in order to create a basis for the new content, recaptured from another meaning province. Now, as Schutz puts it:

"The vacancy is filled in with a new topic, a substitute which belongs to both worlds: to that of the dream, because the vacancy created by dropping the dream-topic still refers to the reality of the dream world left behind by my awakening; and to the world of daily life, because all interpretational and motivational relevances attached to this vacancy belong to this paramount reality (‥)." (Schutz, 1970: pp. 106-107).

This new topic, emerging out of vacuum, is nothing but a symbol in the Schutzian sense:

"A symbol in this sense is thus an enclave in the actual level of reality resulting from the annihilation of a topically relevant theme of experiences originating on another level of reality." (Schutz, 1970: p. 107).

This seems to be the most adequate presentation of an answer to our question of what a critical suspension of belief in the religious sphere of meaning may be in the face of the expand-

${ }^{4}$ See J. Turner's idea of "working hard” in order to intersubjectively negotiate a meaning: Turner, 1988: p. 202. 
ing emancipation of the life-world. It may seem at first glance that Schutz's example of passing from dream to reality disqualifies the application of this type of reflection to our purposes. Religion, if we take into account its self-definition, isn't a kind of imaginary world hovering over reality, but, on the contrary, a domain that claims the right to define reality itself. It is a province of meaning with a strong feedback relation to everyday reality. When something is meant within the religious rationality, it is meant, to a certain extent, within the everyday world, and vice versa: claims to meaning existing within the life-world affect and compete with religious claims.

I submit, though, that this particular feature of religion only strengthens the explanatory power of the Schutzian theory of symbol. Phenomenology is the art of discovering, by some kind of a reflexively performed epoché, these elements of the originally given that are concealed from our sight because they are too close to us. Therefore, it starts by using examples in which the distance is as great as possible and moves toward the others, where the visibility is much worse. "What is Hecuba to the actor?' asks Hamlet. What is Hamlet to us?” asks Schutz. What is the striving to emancipation and career of a pregnant college student to the ideal Catholic, whose commitment to the absolute value of human life simply eliminates the relevance of this topic? What is the absolute value of human life to a fully "secularized" career-maker, whose relevance system cancels the very possibility of considering such a subject? What is the commandment to "love thy neighbor" to the revolting poor, as well as to the rich contemplating his/her economic success, and what is the cry of injustice to the religious believer, who used to neutralize such secondary earthly problems with the perspective of heavenly happiness? The domain of such questions is as vast as it is unexplored. It is certainly not a coincidence that Schutz, well aware of the specific character of religion, poses in this context a remarkable question: "How is it possible that religious experience reveals as a kind of knowledge, the truth of which cannot be grasped by the scheme of interpretational relevances prevailing in the world of daily life?” (Schutz, 1970: pp. 107-108). But, in the face of the modern emancipation of major and minor provinces of meaning, it is also unavoidable to ask how it is possible that these emancipated domains constantly reveal meaning structures that are still unaccounted for by religious belief systems. The process of symbolization is and should be mutual.

\section{What Already Happened and What Is to Be Done. Some Appraisals and Perspectives}

It would be a misunderstanding to suggest that such a mutual process of symbolization remains only an unaccomplished wish. As a matter of fact, it goes on, in a more or less visible manner. As a visible example we may mention the so-called adjective theologies, developing mainly on the grounds of the JudeoChristian tradition (liberation theologies, feminist theologies, etc.), trying to assimilate other relevance systems, and, on the other hand, the increasing notice of human rights in various domains, stimulated by the influence of many religious belief systems. It doesn't cancel, however, the imperative of reflexive intensification of the process in question-for religion, it seems to be a conditio sine qua non of appealing to contemporary plausibility structures, as well as of its mystagogical participation in the human quest for truth. It would be also a misunderstanding to think that symbolization in the sense outlined above leads to a watering down of the identity of religion, since, as suspension of the suspension of belief, it seems to remove shields protecting this identity. In fact, it is rather an internal regroupment of forces, necessary to catch up with the situation on the battle field. It presupposes a constant effort to redefine borders proper to a given province of meaning, in accord with the particular kind of experience inherent to this province. We may mention here a clear example taken from the modern conflict of religion and science: if theologians and inquisition investigators accusing Galileo and Copernicus of heresy had worked more intensively on symbolization of their belief system in reference to changing cosmology, they would have come to conclusions similar to that of Joseph Ratzinger, depicting our marginal position in the cosmos as a perfect reflection of God's logic of maximizing the minimum, corresponding to His own triune nature and His plans in the salvation history (Ratzinger, 1979: pp. 101-104).

This is, of course, not a historical judgment, but rather an operation, speaking the language of Schutz, of projecting modo futuri exacti, i.e., imagining the results of our present actions in terms of effects of the past ones, in this case reprojected onto the scene of the past. We may imagine that way many things in the future: professionally active women raising their children as a standard of social and religious behavior, struggle for social justice and economic success of individuals as a major interest of religious relevance systems, even religious terrorists solving their problems by means of non-violence strategy. Such exercises of the imagination might be helpful and stimulating, but they cannot replace the real work of getting closer to each other, modo praesenti, different relevance structures, inherent to multiple provinces of meaning. Only this effort can help us to avoid real social schizophrenia by strengthening the unity of the counterpointal structure of social consciousness, of the world we all share.

\section{Conclusion. Religion in the World of Plurality and Autonomy}

We may now return to our question about the real meaning of the concept of secularization in the postweberian tradition. Secularization - on the grounds of our considerations-seems to be neither a threat to religious rationality and social order, nor the liberation of Reason (or even of the real faith) from the religious prejudice, but rather a challenge, which religion shares with others provinces of meaning in the face of what we have called the emancipation of the life-world. From the point of view of religious rationality, there is one more reason confirming the thoroughly positive character of this challenge. If religion is a universal human vocation-a claim that contemporary great religious systems would scarcely deny-and if this vocation is compatible with the human quest for meaning, its roots are in the world of everyday life, which is larger and richer than any socially well-defined religious system. And this means, paradoxically, that religion has to reach constantly to the resources of experience, located, at least apparently, beyond its own borders in order to better account for what it is to account for. This affinity of modern social processes and religious goals isn't accidental: the emancipation of the life-world is, after all, in spite of its flaws and crimes, an intensification of the human quest for meaning.

Alfred Schutz, whose sociophenomenology has served in this paper as a basis of interpretation of the postweberian concept of 
secularization, probably discussed this concept explicitly only once, in his review of Eric Voegelin's The new science of politics and Order and history (Voegelin, 1952; Voegelin, 1956; Schutz, 1996). His reluctance to accept Voeglin's point of view on secularization as pagan redivinization of politics and the world as such seems to confirm my application of the Schutzian theory of relevance to the question of religion. Schutz asks why every falling-away of Christian faith understood as a general frame of social order should necessarily mean lethal danger of false divinization of human history. Voegel's argument is right only when one assumes that there is no other access to real meaning than the concept of transcendence delivered by Christian faith: Schutz's response to this assumption is the explicit question whether there cannot be non-Christian experiences of transcendence in the sense of non-Euclidean geometries (Schutz, 1996: p. 230). If the Christian conception of eschaton is accepted as axiomatic, says Schutz, every immanentization of meaning in history may appear to be a Gnostic heresy and an incarnation of evil; but his main point seems to be that Christianity - or even religion as such — is not the only axiomatic system. After all, there are other, non-Euclidean geometries; there are many systems trying to grasp meaning. They all meet where geometry has its origins in the everyday practice of measurement: in the life-world (Husserl, 1970: p. 9).

\section{REFERENCES}

Berger, P. L. (1967). The sacred canopy. Elements of a sociological theory of religion. Garden City, NY: Doubleday.

Bonhoeffer, D. (1971). Letters and papers from prison. In E. Bethge (Ed.), London: SCM Press.

Casanova, J. (1994). Public religions in the modern world. Chicago: University of Chicago Press.

Casanova, J. (2006). Rethinking secularization. A global comparative perspective. The Hedgehog Review, 8, 7-22.
Colliot-Thélène, C. (1995). Rationalisation et désenchantement du monde: Problèmes d'interprétation de la sociologie des religions de Max Weber. Archives de Sciences Sociales des Religions, 89, 61-81.

Cox, H. G. (1990). The secular city. Secularization and urbanization in theological perspective. New York: Collier Books.

Husserl, E. (1970). The crisis of european sciences and transcendental phenomenology. Evanston: Northwestern University Press.

James, W. (1890). The perception of reality. The principles of psychology (Vol. 2, Chap. 21). New York: H. Holt and Company.

Luckmann, Th. (1967). The invisible religion. The problem of religion in modern society. New York: Macmillan.

Martin, D. (1969). The religious and the secular. Studies in secularization. London: Routledge \& K. Paul.

Ratzinger, J. (1979). Introduction to Christianity. New York: Seabury Press.

Schutz, A. (1962), Symbol, reality, and society. In A. Schutz, The problem of social reality (Vol. 1), The Hague: M. Nijhoff.

Schutz, A. (1970). On phenomenology and social relations. Chicago: University of Chicago Press.

Schutz, A. (1970). Reflections on the problem of relevance. New Haven: Yale University Press.

Schutz, A. (1975). Studies in phenomenological philosophy. The Hague: M. Nijhoff.

Schutz, A. (1996). Gnosticism and orthodoxy: Contrasts in fundamental metaphysical and theological positions. Dordrecht/Boston/London: Kluwer Academic Publishers. 221-233.

Turner, J. H. (1988). A theory of social interaction. Stanford, CA: Stanford University Press.

Voegelin, E. (1952). The new science of politics. An introduction. Chicago: University of Chicago Press.

Voegelin, E. (1956). Order and history. Baton Rouge: Louisiana State University Press.

Wagner, H. R. (1970). Introduction. OPSR.

Weber, M. (1963). The sociology of religion. Boston: Beacon Press.

Weber, M. (1975). Max Weber: A biography. New York: Wiley.

Wilson, B. (1982). Religion in sociological perspective. Oxford, NY: Oxford University Press.

Zaner R. M. (1970). Introduction. In A. Schutz, RPR. 